\title{
Obesity contributes toward hypertension in young and older adult
}

\author{
Julianty Pradono* and Sintawati**
}

*Centre for Public Health Research
and Development, NIHRD,
Republic of Indonesia
**Centre for Health Resources and
Services, NIHRD,
Republic of Indonesia

\section{Correspondence:}

Julianty Pradono

Centre for Public Health Research and Development, NIHRD,

Republic of Indonesia

Phone: +62812 1004523

Email: jpradono@yahoo.com

Univ Med 2016;35:96-104

DOI: 10.18051/UnivMed.2016.v35.96-104 pISSN: 1907-3062 / eISSN: 2407-2230

This open access article is distributed under a Creative Commons Attribution-Non Commercial-Share Alike 4.0 International License

\section{BACKGROUND}

Obesity and hypertension are independent risk factors in the increasing prevalence of non-communicable diseases. The proportion of obesity in Indonesia has increased in the last 5 years according to the National Health Survey. The purpose of this research was to obtain the contribution of obesity toward hypertension in the age group of 18 years and above.

\section{METHODS}

An observational study of cross-sectional design was conducted using the National Basic Health Research 2013 population data. The total sample of subjects was 2,741,297 from 33 provinces in Indonesia. Data were collected through interviews, blood pressure measurement, and anthropometry. Analysis of categorical data was by means of the chisquare statistical test, followed by calculation of the attributable fraction in the population, and analysis of factors influencing the impact fraction.

\section{RESULTS}

The prevalence of general obesity $\left(\mathrm{BMI} \geq 25 \mathrm{~kg} / \mathrm{m}^{2}\right)$ was $31.5 \%$ in males and $48.0 \%$ in females, while central obesity was $20.9 \%$ in males and $42.5 \%$ in females. In females with general obesity the risk of hypertension was 1.84 (95\% CI: 1.82-1.86) times higher than in those with normal BMI. If general obesity and central obesity can be reduced, the prevalence of hypertension may be reduced by $2.9 \%$ in males and by $12.2 \%$ in females.

\section{CONCLUSION}

The prevalence of hypertension in the age group of 18 years or more can be reduced by $2.9 \%$ in males and by $12.2 \%$ in females, by overcoming the contribution of obesity. Therefore efforts should be geared towards promoting healthy eating habits and maintaining a healthy weight through health education.

Keywords: Obesity, hypertension, age $\geq 18$ years 


\section{INTRODUCTION}

Obesity is one of the independent risk factors for the increased incidence of coronary heart disease and diabetes mellitus in the population. ${ }^{(1)}$

According to the National Health Survey, the proportion of general obesity in Indonesian males increased from $13.9 \%$ in 2007 to $19.7 \%$ in 2013. In Indonesian females, the proportion of general obesity also increased, from $14.8 \%$ to $32.9 \%$. $^{(2)}$ Similarly, the proportion of central obesity increased from $18.8 \%$ in 2007 to $26.6 \%$ in 2013, both in males and females. The two most common measurements used in population surveys are body mass index (BMI) to indicate general obesity and abdominal circumference to indicate central obesity. During an observation period of 46 years on 508 young adults, a longitudinal cohort study in the US found that BMI scores of $\geq 30 \mathrm{~kg} / \mathrm{m}^{2}$ were substantially associated with the prevalence of hypertension (hazard ratio, 4.17; 95\% confidence interval 2.34-7.42). Similarly, BMI scores of $25-29 \mathrm{~kg} /$ $\mathrm{m}^{2}$ increased the risk of hypertension (hazard ratio $1.58 ; 95 \%$ confidence interval $1.28-1.96){ }^{(3)}$

Another study showed that the risk of hypertension is much greater in men than in women at any given level of BMI. For men, the risk of hypertension is strongly positively associated with BMI only at BMI levels above 25 , but for women a positive relationship is observed at all BMI levels. This indicates that using a BMI cut off point of 25 to define overweight is more appropriate for men than for women. ${ }^{(4)}$ Hypertension is an increase in blood pressure that remains above normal limits. In general, hypertension does not show any symptoms and is usually detected at the time of consultation for a different illness. The results of the Indonesian Basic Health Research (Riskesdas) indicate that the prevalence of hypertension in 2007 was $31.7 \%$ in the age group of 18 years or above. Among the reported prevalences, only $23 \%$ of subjects had ever been diagnosed by health personnel and were taking antihypertensive drugs, whereas $77 \%$ were found upon blood pressure measurement during the survey. Of the subjects who had ever been diagnosed as having hypertension by health personnel, only $24.0 \%$ had their blood pressure controlled and regularly consulted their physician. ${ }^{(5)}$

Obesity in the long term causes injury to target organs, particularly the kidneys. Hypertension caused by obesityis more difficult to control, thus requiring several antihypertensive drugs and treatment of the risk factors, including dyslipidemia, insulin resistence, and diabetes mellitus. ${ }^{(6)}$ The objective of the present study was to determine the level of the contribution of obesity toward the prevalence of hypertension in subjects aged 18 years and over.

\section{METHODS}

\section{Study design}

This observational study was of crosssectional design and was conducted from August until October 2013 in 33 provinces in Indonesia.

\section{Study subjects}

The subjects were individuals aged $\geq 18$ years, who resided in urban and rural areas, and were members of house holds selected as samples in Riskesdas 2013. The inclusion criteria were residents aged $\geq 18$ years, males and female, and agreeing to be interviewed and to under go measurements. The number of subjects meeting the inclusion criteria was $2,918,858$ from 33 provinces in Indonesia. The exclusion criteria were persons with severe illness, who could therefore not be interviewed and were unable to stand or sit for measurements.

\section{Interviews}

Interviews using a questionnaire were performed by trained interviewers. The questionnaire comprised socio demographic characteristics, history of illness, (whether ever diagnosed by health personnel as having hypertension and currently taking anti hypertensive drugs), and behavioral risk factors. 


\section{Measurements}

All subjects under went measurements by trained data collectors. Anthropometric measures comprised body weight, which was measured with a personal balance and expressed in $\mathrm{kg}$, and height, which was measured using a statometer and expressed in $\mathrm{cm}$, on subjects without footwear or belts.

Abdominal circumference was measured using a measuring tape and expressed in $\mathrm{cm}$. Measurement of abdominal circumference was carried out by politely asking the subject to open or lift the outer garments, then with the subject standing upright and breathing normally, determining the midpoints between the lower margin of the last palpable rib and the top of the iliac crest on both sides of the body and marking them with a marking pen. The measuring tape was placed around the subject's abdomen through both midpoints. Central obesity was defined as an abdominal circumference of $>90 \mathrm{~cm}$ for males and $>80 \mathrm{~cm}$ for females. ${ }^{(7)}$

The body mass index was calculated as follows: $\mathrm{BMI}\left(\mathrm{kg} / \mathrm{m}^{2}\right)=$ weight $(\mathrm{kg}) /\left[\right.$ height $\left.(\mathrm{m})^{2}\right]$. Standard BMI scores for Asians are: underweight $<18.5$; normal weight $\geq 18.5-<25.0$; overweight $\geq 25-<27$; and obesity $\geq 27.0$. $^{(7)}$ The WHO showed that the relationships between BMI, percentage of body fat, and health risks in Asian populations differ from those of European populations. The proportion of Asians at high risk of non-communicable disease has a BMI score of $\geq 25 \mathrm{~kg} / \mathrm{m}^{2}$. ${ }^{(7)}$ In the analysis for application in preventive programs, general obesity was defined as a BMI score of $\geq 25 \mathrm{~kg}$ / $\mathrm{m}^{2}$.

Blood pressure was measured using a digital sphygnomanometer. The subjects were asked not to perform physical activity such as sports, at least 30 minutes before undergoing blood pressure measurements. The subjects were asked to sit and rest for at least 5-10 minutes before the measurements. The measurements were performed twice with an interval of 3-5 minutes between two successive measurements, during which interval the cuff around the arm was loosened. If the first and second measurements differed by $\geq 10 \mathrm{mmHg}$, a third measurement was taken after a rest of 10 minutes, with loosening of the cuff around the arm. The recorded systolic and diastolic blood pressure was taken as the mean of 2 of the closest measurements. Hypertension was defined if the systolic blood pressure was $\geq 140 \mathrm{mmHg}$, or the diastolic blood pressure $\geq 90 \mathrm{mmHg}$, or if the subject was taking antihypertensive drugs. ${ }^{(8)}$

\section{Data analysis}

The chi-square test was used to compare the prevalence of obesity between age groups in the population under study. Multiple logistic regression analysis was used to obtaina risk factor model of hypertension, while the odds ratio was used to test for an association between hypertension and several other variables. Furthermore, to determine the level of the contribution of each of these variables, the attributable fraction in the population (AFP) was determined by calculating the adjusted $\mathrm{OR}$ value of the respective risk factor variables.

In astudy of cross-sectional designand using logistic regression analysis, if the frequency is $>10 \%$ and $\mathrm{OR}>2.5$, the calculated $\mathrm{OR}$ value is frequently overestimated. Therefore, to obtain a better estimate of the effect of an association, the adjusted OR should be corrected to estimate the relative risk, which will subsequently be termed the corrected relative risk (RRcor). ${ }^{(9)}$

The RRcor is calculated from the following formula:

$$
\text { RRcor }=\frac{\mathrm{OR}}{\left(1-\mathrm{P}_{0}\right)+\left(\mathrm{P}_{0} \mathrm{xOR}\right)}
$$

where $\mathrm{P} 0=$ out come of non-exposed group, $\mathrm{OR}=$ odds ratio, $\mathrm{RRcor}=$ corrected relative risk.

After obtaining the value of the relationhip of several risk factors and the prevalence of hypertension with corrected relative risk, an analysis is performed on the impact fraction againts these influencing factors. Thus will be known the level of the contribution of each of 
the risk factors toward the dependent variables, yielding a priority scale for intervention programs against these variables.

If the corrected RR is $>1$, the calculated impact fraction is the value of attributable fraction of exposure in the exposed population (AFE), ${ }^{(10)}$ which is calculated using the formula

$$
\mathrm{AFE}=\frac{\text { RRcor }-1}{\text { RRcor }}
$$

The attributable fraction in the whole population (AFP) is then

$$
\mathrm{AFP}=\frac{\mathrm{a}}{(\mathrm{a}+\mathrm{c})} * \mathrm{AFE}
$$

where $a=$ number of subjects at risk of hypertension, and $(\mathrm{a}+\mathrm{c})=$ all subjects with hypertension. The level of contribution of the risk factors is calculated as follows: Level of contribution $=$ AFP $*$ Proportion of exposed outcome. The analysis was performed using the SPSS version $15.0^{\circledR}$ software.

\section{Ethical clearance}

The Basic Health Research (Riskesdas) for the year 2013 had already been granted ethical clearance from the Ethics Commission, National Institute for Health Research and Deveopment,
Ministry of Health, Republic of Indonesia, under number LB.02.01/5.2/KE.006/2013.

\section{RESULTS}

Among the 2,918,858 subjects in the age group of 18 years and over who participated in the interviews, a total of 2,741,297 (93.9\%) subjects had complete data and anthropometric measures.

The number of male subjects was $1,284,299$ (46.9\%), and that of the females $1,456,998(53.1 \%)$. Mean age of the subjects was $43.18 \pm 14.23$ years, with no significant difference in mean age between males and females. Mean height and weight were higher in males than in females. The converse was true for the means of BMI, abdominal circumference, and diastolic blood pressure (Table 1). The prevalences of general obesity (BMI $\geq 25 \mathrm{~kg} / \mathrm{m}^{2}$ ), central obesity, hypertension, and smoking behavior were $30.4 \%, 29.5 \%, 29.8 \%$ and $32.6 \%$, respectively. These prevalences, except that for smoking behavior, were higher in females than in males. The educational level of the female subjects was lower than that of the males. More than half of the females had only primary school education, did not finish primary school, or never went to school (Table 1).

\begin{tabular}{|c|c|c|c|c|}
\hline Charac teristic & $\begin{array}{c}\text { Total } \\
(n=2,741,297)\end{array}$ & $\begin{array}{c}\text { Males } \\
(n=1,284,299)\end{array}$ & $\begin{array}{c}\text { Fe males } \\
(n=1,456,998)\end{array}$ & $\mathbf{p}$ \\
\hline $\mathrm{H}$ ei ght $(\mathrm{cm})$ & $43.18 \pm 14.23$ & $43.69 \pm 14.41$ & $42.733 \pm 14.05$ & 0.000 \\
\hline Weight ( $\mathrm{K}$ g) & $156.39 \pm 8.43$ & $162.16 \pm 6.76$ & $151.33 \pm 6.21$ & 0.000 \\
\hline$B$ ody $m$ ass index & $56.82 \pm 11.17$ & $99.16 \pm 10.82$ & $54.77 \pm 11.07$ & 0.000 \\
\hline A bdominal circumference $(\mathrm{cm})$ & $23.22 \pm 4.23$ & $22.46 \pm 3.65$ & $23.89 \pm 4.59$ & 0.000 \\
\hline Systolic BP (m mH g) & $78.93 \pm 10.94$ & $78.11 \pm 10.19$ & $79.65 \pm 11.50$ & 0.000 \\
\hline Diastolic $\mathrm{BP}(\mathrm{m} \mathrm{mH})$ & $127.38 \pm 21.04$ & $127.49 \pm 18.58$ & $127.28 \pm 22.99$ & 0.063 \\
\hline $\mathrm{G}$ eneral obesity $(\mathrm{n}, \%)$ & $832,459(30.4)$ & $278,479(21.7)$ & $553,980(38.0)$ & 0.000 \\
\hline $\mathrm{C}$ entral doesity $(\mathrm{n}, \%)$ & $809,817(29.5)$ & $154,305(12.0)$ & $655,512(45.0)$ & 0.000 \\
\hline Hypertensi on $(n, \%)$ & $814,800(29.8)$ & $338,170(26.3)$ & $476,630(32.7)$ & 0.000 \\
\hline Smoking $(n, \%)$ & $892,381(32.6)$ & $857,454(66.8)$ & $34,927(2.4)$ & 0.000 \\
\hline \multicolumn{5}{|l|}{ Education } \\
\hline No education (\%) & $172,767(6.3)$ & $61,646(4.8)$ & $111,121(7.6)$ & 0.000 \\
\hline N ot firishing prim ary school (\%) & $359,280(13.1)$ & $153,780(12.0)$ & $205,500(14.1)$ & \\
\hline Prim ary shool $(\%)$ & $854,946(31.2)$ & $382,577(29.8)$ & $472,369(32.4)$ & \\
\hline Jurior high school (\%) & $463,337(16.9)$ & $225,666(17.6)$ & $237,671(16.3)$ & \\
\hline Serior high school (\%) & $682,983(24.9)$ & $358,748(27.9)$ & $324,235(22.3)$ & \\
\hline Diplomat(\%) & $207,984(7.6)$ & $101,882(7.9)$ & $106,102(7.3)$ & \\
\hline
\end{tabular}

Table 1.Comparison of several characteristics between genders 
Table 2. Prevalences of general obesity, central obesity and hypertension by age group and gender

\begin{tabular}{lcccc}
\hline Age (yr) & $\mathbf{n}$ & General obesity & Central obesity & Hypertension \\
\hline Males (\%) & & & & \\
$18-24$ & 132,472 & $6,265(4.7)$ & $5,697(3.7)$ & $13,429(36)$ \\
$25-34$ & 231,095 & $20,703(15.6)$ & $19,815(12.8))$ & $34,462(93)$ \\
$35-44$ & 328,826 & $41,165(31.0)$ & $44520(28.9)$ & $75,079(20.4)$ \\
$45-54$ & 298,651 & $38,222(28.8)$ & $46,584(30.2)$ & $100,308(27.2)$ \\
$55-64$ & 187,058 & $21,035(15.9)$ & $28,139(18.2)$ & $84,202(22.8)$ \\
$65-74$ & 80,245 & $4,228(3.2)$ & $7,912(5.1)$ & $45,063(12.2)$ \\
$75+$ & 25,952 & $1,033(0.8)$ & $1,638(1.1)$ & $16,097(4.4)$ \\
p & - & 0.000 & 0.000 & 0.000 \\
Females (\%) & & & & \\
$18-24$ & 134,788 & $11,194(3.5)$ & $24,305(3.7)$ & $11,587(22)$ \\
$25-34$ & 314,704 & $62,631(19.4)$ & $125,828(19.2)$ & $57,844(10.9)$ \\
$35-44$ & 398,551 & $109,044(33.8)$ & $204,786(31.2)$ & $131,935(24.9)$ \\
$45-54$ & 316,925 & $88,131(27.4)$ & $174,801(26.7)$ & $151,117(28.6)$ \\
$55-64$ & 182,207 & $39,655(12.3)$ & $89,345(13.6)$ & $102,025(19.3)$ \\
$65-74$ & 79,512 & $9,262(2.9)$ & $28,362(4.3)$ & $53,043(10.0)$ \\
$75+$ & 30,311 & $2,280(0.7)$ & $8,085(1.2)$ & $21,549(4.1)$ \\
p & - & 0.000 & 0.000 & 0.000 \\
\hline
\end{tabular}

General obesity $=$ BMI $\geq 25 \mathrm{~kg} / \mathrm{m}^{2}$

The prevalences of general obesity in the males of the age groups of 18 up to 44 years were on average lower than those in the females, but the opposite was found in the age groups of 45 years and over (Table 2).

After controlling for age, educational level, and smoking behavior, females with general obesity had a 1.84-fold higher risk (95\% CI: $1.82-$ 1.86) for hypertension than females with normal BMI, while males with general obesity had a 1.69- fold higher risk (95\% CI: 1.68-1.71) for hypertension than males with normal BMI. After controlling for age, educational level, and smoking behavior, males with central obesity $(>90 \mathrm{~cm})$ had a 1.94-fold higher risk (95\% CI: 1.91-1.96) than those with an abdominal circumference of $\leq 90$ $\mathrm{cm}$. On the other hand, females with central obesity $(>80 \mathrm{~cm})$ had a 1.53 -fold higher risk $(95 \%$ CI: 1.51-1.54) than those with an abdominal circumference of $\leq 80 \mathrm{~cm}$ (Table 3 ).

Table 3. Relationship of BMI and abdominal circumference with hypertension, by gender

\begin{tabular}{|c|c|c|c|}
\hline Gender & n (\%) & Hypertensionn (\%) & $\mathrm{OR} *(95 \% \mathrm{CI})$ \\
\hline Males & $1,284,299(46.9)$ & $368,640(28.7)$ & \\
\hline \multicolumn{4}{|l|}{ BMI $\left(\mathrm{kg} / \mathrm{m}^{2}\right)$} \\
\hline $\mathrm{BMI}<18.5$ & $138,639(10.8)$ & $31,637(8.6)$ & $0.76(0.75-0.77)$ \\
\hline BMI 18.5-24.9 & $872,376(67.9)$ & $220,775(99.9)$ & 1.0 \\
\hline $\mathrm{BMI} \geq 25$ & $273,284(21.3)$ & $116,228(31.5)$ & $1.69(1.68-1.71)$ \\
\hline \multicolumn{4}{|c|}{ Abdam inal circumference $/ \mathrm{AC}(\mathrm{cm})$} \\
\hline$A C>90$ & $154,305(12.0)$ & $76,941(20.9)$ & $1.94(1.91-1.96)$ \\
\hline $\mathrm{AC} \leq 90$ & $1,129,994(88.0)$ & $291,699(79.1)$ & 1.0 \\
\hline Females & $1,456,998(53.1)$ & $529,100(36.3)$ & \\
\hline \multicolumn{4}{|l|}{$\mathrm{BMI}\left(\mathrm{kg} / \mathrm{m}^{2}\right)$} \\
\hline $\mathrm{BMI}<18.5$ & $133,083(9.1)$ & $38,301(7.2)$ & $0.79(0.78-0.81)$ \\
\hline BMI 18.5-24.9 & $794,915(54.6)$ & $236,892(44.8)$ & 1.0 \\
\hline $\mathrm{BMI} \geq 25$ & $529,000(36.3)$ & $253,907(48.0)$ & $1.84(1.82-1.86)$ \\
\hline \multicolumn{4}{|c|}{ Abdam inal circumference $/ \mathrm{AC}(\mathrm{cm})$} \\
\hline $\mathrm{AC}>80$ & $655,512(45.0)$ & $304,295(57.5)$ & $1.53(1.51-1.54)$ \\
\hline $\mathrm{AC} \leq 80$ & $801,486(55.0)$ & $224,805(42.5)$ & 1.0 \\
\hline
\end{tabular}

BMI=body mass index; $\mathrm{AC}=$ abdominal circumference; *controlled for age, educational level, smoking 
Table 4. Reduction in prevalence of hypertension if risk factors of obesityare eliminated

\begin{tabular}{lccccc}
\hline \multicolumn{1}{c}{ Variable } & RRcor & $\begin{array}{c}\text { AFE } \\
\text { (\%) }\end{array}$ & $\begin{array}{c}\text { AFP } \\
\text { (\%) }\end{array}$ & $\begin{array}{c}\text { Contribution } \\
\text { (\%) }\end{array}$ & $\begin{array}{c}\text { Final prevalence } \\
\text { (Baseline prevalence) (\%) }\end{array}$ \\
\hline Males & & & & & \\
BMI $\geq 25 \mathrm{~kg} / \mathrm{m}^{2}$ & 1.15 & 12.9 & 4.1 & 1.9 & $29.6(31.5)$ \\
Central obesity & 1.11 & 10.1 & 2.1 & 1.0 & $19.9(20.9)$ \\
T otal & & & & 2.9 & $25.8(28.7)$ \\
Fem ales & & & & & \\
BMI $\geq 25 \mathrm{~kg}^{2} \mathrm{~m}^{2}$ & 1.28 & 21.9 & 10.5 & 5.6 & $42.4(48.0)$ \\
Central obesity & 1.27 & 21.5 & 12.4 & 6.6 & $35.9(42.5)$ \\
Total & & & & 12.2 & $24.1(36.3)$ \\
\hline
\end{tabular}

If both risk factors, namely general obesity $\left(\right.$ BMI $\left.\geq 25 \mathrm{~kg} / \mathrm{m}^{2}\right)$ and central obesity, are eliminated, the contribution in males will be $2.9 \%$, the prevalence of hypertension may be reduced from $28.7 \%$ to $25.8 \%$. In contrast, the contribution in females will be $12.2 \%$, the prevalence of hypertension may be reduced from $36.3 \%$ to $24.1 \%$ (Table 4).

\section{DISCUSSION}

The prevalence ofobesity in residents aged 18 years and above was $30.4 \%$ (21.7\% in males and $38.0 \%$ in females), with the prevalence in females being significantly higher than in males. These results are consistent with the findings in the study by Wang et al. ${ }^{(11)}$ in China.The prevalence of central obesity was $12.0 \%$ in males and $45.0 \%$ in females, showing significant results. These values are lower than those of Wang et al. ${ }^{(11)}$ in China. This may have been due to the use of different age groups in both studies. The study by Wang used subjects aged 50 years and over from urban areas, where as the present study used subjects aged 18 years and older from both urban and rural areas.

The prevalence of general obesity increased with age, in males as well as females. The highest prevalence of general obesity was in the age group of 35-44 years. Central obesity showed significant differences by age group, both in males and females. In males the highest prevalence occurred at a 10-year younger age, i.e. in the age group of 35-44 years. These results show that the third and fourth decades are very important in the development of central obesity, particularly in females. ${ }^{(12)}$

From the prevalence of general and central obesity in our study, it is apparent that if these can be prevented or controlled, the prevalence of hypertension in both males and females in the age group of 18 years and over in Indonesia may be lowered and with due attention to other risk factors, may impede the development of noncommunicable disease.

Numerous studies have shown that the risk of hypertension is increased in persons with obesity, and that the relationship between obesity and hypertension varies with age, gender, geographic area, and race. ${ }^{(13)}$ In the analysisof the relationship between obesity and hypertension in residents aged 18 years and above in Indonesia, it was shown that height, weight, and the prevalences of general obesity (BMI), central obesity, blood pressure, smoking and educational level differed significantly between males and females. This indicates that gender is a strong confounding variable, although the sample sizes of the males and females were almost balanced.

According to the WHO, the definition for overweight and general obesity in Caucasian populations are 25 and $30 \mathrm{~kg} / \mathrm{m}^{2}$, respectively. ${ }^{(14)}$ On the other hand, studies in China and many other Asian countries showed that their population shad lower BMI scores but higher percentages of body fat in comparison with European countries. ${ }^{(15)}$

The relationship between obesity and hypertension may be explained as being due to 
the role of leptin-releasing adipose tissue. ${ }^{(16)}$ Leptin isan adipose tissue-derived hormone that plays a rolein interactions involving increased blood pressure, in association with metabolic, inflammatory, hemostatic, and other factors. This was demonstrated in the US National Health and Nutritional Examination Survey in the age group of 20 years or above $(n=5,599$; females $54.7 \%)$. The plasma leptin concentration was categorized in quartiles (females: <7.68, 7.68-13.18, 13.1921.70, >21.70 fg/L; males: <2.64, 2.64-4.36, 4.37-7.12, >7.12 fg/L), showing that plasma leptin concentration was higher and positively associated with hypertension, after having been controlled for age, gender, ethnicity, education, smoking, alcohol intake, BMI, diabetes mellitus, serum cholesterol and C-reactive protein. In comparison with the first quartile leptin (reference), the odds ratio for hypertension associated with the fourth quartile leptin was 1.89 (95\% CI: 1.24-2.09). Subgroup analysis by gender and BMI also showed a consistently positive association. ${ }^{(17)}$

Shidfar et al. ${ }^{(18)}$ in their study stress the importance of attention to changes in body fat distribution that lead to increased risks for cardiac and metabolic disease, particularly in menopause. A cross-sectional study on 138 females in the age group of 26-35 years showed significantly increase in blood pressures (systolic and diastolic) in subjects within creased BMI and central obesity, in comparison with subjects who had normal BMI and no central obesity.BMI and abdominal circumference showed a significant positive correlation with systolic and diastolic blood pressure, and had several independent effects on therisk of high blood pressure in females. ${ }^{(19)}$ Central obesity is a better predictor than general obesity for the risk of cardiovascular disease in females. ${ }^{(20)}$ Hypertension is strongly correlated with obesity, ${ }^{(21)}$ which is consistent with our study results confirming a correlation between hypertension, general obesity and central obesity.

There is an agreement between countries, which is known as the $25 \times 25$ target, to reduce premature mortality as a result of the four main non-communicable diseases (cardiovascular disease, chronic respiratory disease, cancer, and diabetes) by $25 \%$ from 2010 to 2025, between the ages of 30 to 70 years. International studies of various countries have shown that, upon achievement of the risk factor target, the probablity of death from the four main noncommunicable diseases will decrease by $22 \%$ in malesand by $19 \%$ in females between the years 2010 and 2025. Achieving the risk factor target will delay the death of more than 37 million persons, which will be mostly felt inlow-to middleincome countries. ${ }^{(22)}$

The sample in this study has a considerably high power in the national population, thus allowing for a correct estimate of the contribution of obesity to ward the prevalence of hypertension among the study subjects. One limitation of this study is that $6.1 \%$ of respondents had incomplete data. In addition, errors in blood pressure measurement are more freqnent in obese persons, if a cuff of the wrong size is used. Although an analysis of the risk factors of hypertension was performed, including smoking and educational level, there are presumably other risk factors that may affect the contribution of obesity toward hypertension, but were not included in the analysis. The study design used was crosssectional, which cannot explain any cause-andeffect relationship.

The nationally-based study results reveal that a reduction in general obesity and central obesity may reduce the prevalence of hypertension, particularly in females of the third or fourth decades. Further studies are needed to identify increased obesity as an impediment in the management of hypertension, which continuously threatens to increase the number of persons with non-communicable disease. On the other hand, decreases in weight may be associated with reductions in blood pressureand risk of non-communicable disease, particularly cardiovascular disease. ${ }^{(23)}$ Strategies should be developed for optimal increases in interventions or interventional therapies for hypertension due to obesity. 


\section{CONCLUSION}

The prevalence of hypertension in the age group of 18 years or more can be reduced by $2.9 \%$ in males and by $12.2 \%$ in females, by over coming the contribution of obesity. Therefore efforts should be geared towards promoting healthy eating habits and maintaining a healthy weight through health education.

\section{CONFLICT OF INTERESTS}

No relevant conflict of interest present.

\section{ACKNOWLEDGEMENT}

We extend our thanks to the Head and Secretariat of the Health Research and Development Agency, Ministry of Health, Republic of Indonesia, who gave us the opportunity for further analysis of the Riskesdas 2013 data. We also thank the data laboratory that provided the data for analysis.

\section{REFERENCES}

1. Scheuer SH, Ferch K, Philipsen A, et al. Abdominal fat distribution and cardiovascular risk in men and women with different levels of glucose tolerance. J Clin Endocrinol Metab 2014;100. DOI: http://dx.doi.org/10.1210/ JC.2014-4479.

2. Badan Penelitian dan Pengembangan Kesehatan. Riset kesehatan dasar Indonesia 2013: Laporan nasional. Jakarta: Badan Penelitian dan Pengembangan Kesehatan;2013.

3. Shihab HM, Meoni LA, Chu AY, et al. Body mass index and risk of incident hypertension over the life course: The Johns Hopkins Precursors study. Circulation 2012;126:2983-89. doi: 10.11610. 1161/CIRCULATIONAHA.112.117333.

4. Mishra V, Arnold F, Semenov G, et al. Epidemiology of obesity and hypertension in Uzbekistan. United States Agency for International Development;2005.

5. Badan Penelitian dan Pengembangan Kesehatan Kementerian Kesehatan R.I. Laporan Riskesdas Biomedis. Jakarta: Badan Penelitian dan Pengembangan Kesehatan;2009.

6. Hall JE, do Carmo JM, da Silva AA, et al. Obesity-induced hypertension: interaction of neurohumoral and renal mechanisms. Circ Res 2015;116:991-1006.

7. WHO expert consultation. Appropriate bodymass index for Asian populations and its implications for policy and intervention strategies. Lancet 2004;363:157-63 .

8. James PA, Oparil S, Carter BL, et al. Evidencebased guideline for the management of high blood pressure in adults: Report from the panel members appointed to the Eighth Joint National Committee (JNC 8). JAMA 2014;311:507-20.

9. Gordis L. Epidemiology. $5^{\text {th }}$ ed. Phyladelphia: Elsevier Saunders;2014.

10. Gerstman BB. Epidemiology kept simple: an introduction to traditional and modern epidemiology. $3^{\text {rd }}$ ed. Oxford: Wiley-Blackwell; 2013.

11. Wang SK, Ma W, Wang S, et al. Obesity and Its relationship with hypertension among adults 50 years and older in Jinan, China. PLoS ONE 2014;9:e114424. Doi:10.1371.

12. Park JK, Lim YH, Kim KS, et al. Changes in body fat distribution through menopause increase blood pressure independently of total body fat in middle-aged women: the Korean National Health and Nutrition Examination Survey 2007-2010. Hypertens Res 2013;36:444-9.

13. Wakabayashi I. Age-dependent influence of gender on the association between obesity and a cluster of cardiometabolic risk factors. Gend Med 2012;9:267-77.

14. Bosy-Westphal A, Geisler C, Onur S, et al. Value of body fat mass vs anthropometric obesity indices in the assessment of metabolic risk factors. Int J Obes 2006;30:475-83.

15. Razak F, Anand SS, Shannon H, et al. Defining obesity cut points in a multiethnic population. Circulation 2007;115:2111-8.

16. Allison MA, Joachim H, Morgan C, et al. Higher leptin is associated with hypertension: the multiethnic study of atherosclerosis. J Hum Hypertens 2013;27: 617-22. doi: 10.1038/jhh.2013.24.

17. Shankar A, Xiao J. Positive relationship between plasma leptin level and hypertension. Hypertension 2010;56:623.

18. Shidfar F, Alborzi F, Salehi M, et al. Association of waist circumference, body mass index and conicity index with cardiovascular risk factors in postmenopausal women. Cardiovase J Afr 2012;23:442-5.

19. Kanthe P, Patil BS, Shaikh GB. Association between central obesity parameters and blood pressure phenotypes: study among women. Int J Pharma Bio Sci 2015;6:B355-B61.

20. Goh LGH, Dhaliwal SS, Welborn TA, et al. Anthropometric measurements of general and 
central obesity and the prediction of cardiovascular disease risk in women: a crosssectional study. BMJ Open 2014;4:e004138. doi:10.1136/bmjopen -2013-004138.

21. Pajunen P, Jousilahti P, Borodulin K, et al. Body fat measured by a near-infrared interactance device as a predictor of cardiovascular events: the FINRISK'92 cohort. Obesity 2011;19:84852.

22. Kontis V, Mathers CD, Rehm J, et al. Contribution of six risk factors to achieving the $25 \times 25$ non-communicable disease mortality reduction target: a modelling study. Lancet 2014; 384:427-37. 